\title{
AKTIVITAS ANTIOKSIDAN DAN KANDUNGAN FENOLIK TOTAL DARI ISOLAT POLAR FRAKSI HEKSANA EKSTRAK ETANOL DAUN SIRIH (PIPER BETLE L.)
}

\author{
Fadilah Qonitah', Ahwan' \\ ${ }^{1}$ Program Studi Farmasi, Fakultas Sains dan Teknologi, Universitas Sahid Surakarta \\ fadilahqonitah12@gmail.com
}

\begin{abstract}
ABSTRAK
Antioksidan merupakan senyawa yang dapat meredam radikal bebas. Sirih (piper betlle L.) termasuk tanaman yang mengandung komponen senyawa kimia yang mempunyai efek tertentu terhadap pengobatan (antidiabetes, antiinflamasi dan antioksidan). Penelitian ini dilakukan untuk mengetahui aktivitas antioksidan dan kandungan fenolik total dari isolat polar fraksi heksana ekstrak etanol daun sirih. Aktivitas antioksidan ditentukan dengan metode peredaman radikal DPPH (2,2-difenill-1pikrilhidrazil). Kandungan fenolik total ditentukan dengan metode spektrofotometri. Hasil penelitian menunjukkan bahwa isolat polar fraksi heksana ekstrak etanol daun sirih mempunyai aktivitas antioksidan sangat kuat $\left(\mathrm{IC}_{50} 37,37 \mu \mathrm{g} / \mathrm{mL}\right)$, akan tetapi aktivitas antioksidan tersebut lebih kecil daripada vitamin $\mathrm{E}\left(\mathrm{IC}_{50} 8,41 \mu \mathrm{g} / \mathrm{mL}\right)$. Kandungan fenolik total isolat polar fraksi heksana ekstrak etanol daun sirih sebesar 23,43 $\pm 1,19 \% \mathrm{~b} / \mathrm{b}$ EAG.
\end{abstract}

Kata Kunci: antioksidan, fenolik total, daun sirih, DPPH (2,2-difenil-1-pikrilhidrazil)

\section{ANTIOXIDANT ACTIVITIES AND TOTAL PHENOLIC CONTENTS FROM HEKSANA POLAR FRACTION ISOLATE SIRAN LEAF ETHANOL EXTRACT (PIPER BETLE L.)}

\begin{abstract}
Antioxidants are compounds that can reduce free radicals. Betel (piper betlle L.) includes plants that contain components of chemical compounds that have certain effects on treatment (antidiabetic, antiinflammatory and antioxidants). This study was conducted to determine the antioxidant activity and total phenolic content of polar isolates of hexane fraction of betel leaf ethanol extract. Antioxidant activity was determined by the DPPH (2,2-difenill-1-pikrilhidrazil) radical reduction method. Total phenolic content was determined by the spectrophotometric method. The results showed that polar isolates of hexane fraction of betel leaf ethanol extract had very strong antioxidant activity (IC50 $37.37 \mu \mathrm{g} / \mathrm{mL})$, but the antioxidant activity was smaller than vitamin E (IC50 $8.41 \mu \mathrm{g} / \mathrm{mL})$. The total phenolic content of polar isolates of hexane fraction of betel leaf ethanol extract was $23.43 \pm 1.19 \%$ $b / b E A G$.
\end{abstract}

Keywords: antioxidants, total phenolic, betel leaf, DPPH (2,2-diphenyl-1-pikrilhidrazil)

\section{PENDAHULUAN}

Beberapa penyakit seperti kanker, diabetes melitus, aterosklerosis, penyakit kardiovaskuler, penuaan, dan penyakit peradangan disebabkan oleh stres oksidatif sebagai hasil dari ketidakseimbangan antara pembentukan dan netralisasi dari radikal bebas. Radikal bebas merupakan molekul yang tidak stabil mengandung elektron tidak berpasangan. Radikal bebas di dalam tubuh akan bereaksi dengan makromolekul biologis seperti protein, lipid dan DNA dalam sel manusia yang sehat sehingga menyebabkan kerusakan protein, peroksidasi lipid dan kerusakan DNA (Gosh, 2013).

Antioksidan merupakan senyawa yang dapat menghambat reaksi oksidasi lipid atau molekul lain dengan menghambat inisiasi atau propagasi reaksi oksidasi berantai. Antioksidan eksogen terdiri dari antioksidan alami dan antioksidan sintetik. Adanya kekhawatiran terhadap efek samping penggunaan antioksidan sintetik yang dapat meningkatkan karsinogenesis maka mendorong penggunaan antioksidan alami sebagai alternatif sumber antioksidan (Rohman dkk., 2007). 
Antioksidan alami dapat diperoleh dari tanaman dan buah-buahan. Senyawa fenolik merupakan senyawa yang mempunyai aktivitas antioksidan yang banyak ditemukan pada tanaman. Banyak penelitian telah melaporkan bahwa ada hubungan antara senyawa fenolik dan polifenol pada tanaman dengan aktivitas antioksidannya (Fidrianny dkk., 2015).

Sirih (Piper betle L.) merupakan tanaman obat yang sering digunakan karena berkhasiat untuk menghentikan pendarahan, sariawan, gatalgatal dan lain-lain. Ekstrak daun sirih digunakan sebagai obat kumur dan batuk. Ekstrak daun sirih juga berkhasiat sebagai antijamur pada kulit (Moeljatno, 2003). Selain itu senyawa murni dan fraksi dari ekstrak daun sirih juga mempunyai aktivitas antidiabetes, kardiovaskular,antiinflamasi, antioksidan, dan antiplatele (Sumarya dkk., 2016). Berdasarkan data tersebut, penelitian ini dilakukan untuk mengetahui aktivitas antioksidan dan kandungan fenolik total dari isolat polar fraksi heksana ekstrak daun sirih.

\section{METODE}

Bahan yang digunakan dalam penelitian ini adalah daun sirih (Piper betle L.) yang diperoleh dari Palur, Kabupaten Karanganyar, Jawa Tengah, DPPH (2,2-diphenyl-1picrylhidrazil), vitamin $\mathrm{E}$, asam galat, natrium karbonat, pereaksi Folin-Ciocalteu, etanol, heksana, aquades, etil asetat dan toluene.

Alat yang digunakan dalam penelitian ini adalah seperangkat alat maserasi, perangkat alat kromatografi cair vakum, Vacuum rotary evaporator (Buchi), mikropipet (Secorex), yellow tip, blue tip, oven (memmert), lampu UV $254 \mathrm{~nm}$ dan $366 \mathrm{~nm}$, spektrofotometer UV-VIS (shimadzu), alat-alat gelas.

Adapun prosedur pelaksanaannya sebagai berikut: Sebanyak 2000 gram daun sirih yang telah diserbuk dimaserasi dengan etanol sebanyak $14000 \mathrm{~mL}$ dalam wadah stainless yang tertutup rapat dan didiamkan selama 24 jam sambil diaduk-aduk. Setelah itu sampel disaring dan residu dimaserasi kembali dengan etanol sebanyak 2 kali sehingga diperoleh residu dan filtrat etanol. Filtrat etanol yang diperoleh dipekatkan dengan rotary evaporator, sehingga didapat ekstrak kental etanol daun sirih sebanyak 90 gram. Diambil 40 gram dilakukan fraksinasi menggunakan heksana dengan metode partisi. Dari hasil ini diperoleh tiga fraksi yaitu non polar, semipolar dan polar. Seluruh fraksi yang dihasilkan dideteksi dengan Kromatografi Lapis Tipis (KLT) menggunakan eluen gabungan toluene:etil asetat $=9: 1$. Proses selanjutnya untuk memperoleh isolat polar fraksi heksana ekstrak etanol dilakukan proses isolasi dari fraksi heksana. Isolat polar dari fraksi heksana ekstrak etanol daun sirih selanjutnya diukur kandungan fenolik totalnya dan dilakukan uji aktivitas antioksidan dengan metode DPPH (Haryoto, 2007).

Penentuan Aktivitas Antioksidan

Aktivitas antioksidan dalam isolat polar fraksi heksana ekstrak etanol daun sirih ditentukan dengan metode peredaman radikal DPPH sebagai berikut:

Pembuatan larutan pereaksi DPPH,

Ditimbang seksama DPPH 15,77 mg, kemudian dilarutkan dengan etanol p.a sampai tanda pada labu takar 50,0 mL, sehingga diperoleh konsentrasi $0,015 \%$ dan disimpan dalam wadah gelap (Sreenivasan dkk., 2007).

Penentuan panjang gelombang maksimum ( $\left.\lambda_{\text {maks }}\right)$

Larutan stok DPPH 0,015\% sebanyak $1,0 \mathrm{~mL}$ ditempatkan dalam labu takar 5,0 $\mathrm{mL}$ ditambah dengan etanol p.a sampai tanda, diukur absorbansinya pada panjang gelombang 450$545 \mathrm{~nm}$ terhadap blanko $5,0 \mathrm{~mL}$ etanol p.a, diplotkan harga absorbansi maksimum.Panjang gelombang maksimum adalah panjang gelombang dimana larutan cuplikan memiliki absorbansi maksimum. Pada penelitian ini diperoleh panjang gelombang maksimum 520 nm.

\section{Penentuan operating time}

Larutan stok DPPH 0,015\% sebanyak 1,0 mL ditambahkan $0,100 \mathrm{~mL}$ sampel (isolat polar fraksi heksan ekstrak etanol daun sirih) $1 \%$ $\mathrm{b} / \mathrm{v}$, ditambah etanol p.a sampai $5,0 \mathrm{~mL}$ kemudian divorteks selama 30 detik dan diukur pada panjang gelombang $(\lambda)$ maksimum, diplotkan harga absorbansi dengan waktu. Operating time dalam penelitian ini adalah 30 menit Operating time adalah waktu yang dibutuhkan untuk mendapatkan absorbansi yang stabil (Molyneux, 2003; Rohman dkk., 2005; Sreenivasan dkk., 2007) 
Penentuan aktivitas antioksidan peredaman radikal DPPH

Beberapa seri konsentrasi sampel yang telah dibuat ditambah 1,0 mL DPPH 0,015\% dan etanol p.a hingga 5,0 mL. Campuran divortek selama 30 detik dan diinkubasi selama operating time (30 menit). Absorbansi diukur pada panjang gelombang maksimum terhadap blangko (etanol p.a). Dilakukan juga pengukuran absorbasi kontrol yang terdiri atas $1,0 \mathrm{~mL}$ DPPH dan etanol p.a hingga $5,0 \mathrm{~mL}$ pada waktu tertentu. Besarnya aktivitas peredaman radikal menurut Sreenivasan dkk. (2007) dihitung dengan rumus:

$$
\begin{aligned}
& \text { \%peredaman } \\
& =\frac{\text { Abs }_{\text {kontrol }}-\boldsymbol{A b s}_{\text {sampel }}}{A b s_{\text {kontrol }}} \times 100 \%
\end{aligned}
$$

Sebagai pembanding digunakan vitamin $\mathrm{E}$ yang sudah diketahui sebagai antioksidan

Analisis perhitungan aktivitas antioksidan peredaman radikal DPPH

Penelitian ini parameter yang digunakan untuk menyatakan aktivitas antioksidan dengan nilai $\mathrm{IC}_{50}$ yaitu konsentrasi penghambatan yang dapat mereduksi radikal DPPH sebesar 50\% diperoleh dari kurva regresi linier antara aktivitas penghambatan radikal DPPH dengan konsentrasi sampel. Nilai $\mathrm{IC}_{50}$ merupakan indikasi terhadap besarnya aktivitas antioksidan, semakin kecil nilai $\mathrm{IC}_{50}$ menunjukkan bahwa aktivitas antioksidan semakin besar (Rohman, dkk, 2005).

Kandungan fenolik total dalam penelitian ini ditentukan dengan metode spektrofotometri visibel dengan pereaksi Folin-Ciocalteu sesuai dengan Chun dkk. (2003) sebagai berikut: sejumlah sampel uji dimasukkan dalam labu ukur $10 \mathrm{~mL}$, ditambah dengan reagen FolinCiocalteu sebanyak $0,4 \mathrm{~mL}$ dan $\mathrm{Na}_{2} \mathrm{CO}_{3} 7 \%$ sebanyak $4 \mathrm{~mL}$. Campuran dicukupkan dengan aquades sampai batas tanda selanjutnya diikubasi selama 1 jam dan diukur absorbansinya pada panjang gelombang 765 $\mathrm{nm}$ dengan spektrofotometer UV-Vis. Kadar fenolik total dinyatakan dalam $\% \mathrm{~b} / \mathrm{b}$ ekivalen asam galat (\% b/b EAG).

\section{HASIL}

Hasil aktivitas antioksidan isolat polar dari fraksi heksana ekstrak etanol daun sirih dapat dilihat pada Tabel 1. Sedangkan Hasil penentuan kandungan fenolik total dari isolat polar fraksi heksana ekstrak etanol daun sirih dapat dilihat pada Tabel 2.

Tabel 1 .

\begin{tabular}{|c|c|c|}
\hline Konsentrasi $(\mu \mathrm{g} / \mathrm{mL})$ & Rata-rata aktivitas antioksidan (\%) & $\begin{array}{c}\text { Rata-rata } \mathrm{IC}_{50} \\
(\mu \mathrm{g} / \mathrm{mL})\end{array}$ \\
\hline 13,08 & $14.75 \pm 0.10$ & \multirow[b]{5}{*}{ ol daun sirih } \\
\hline 21,80 & $28.44 \pm 0.54$ & \\
\hline 30,52 & $46.24 \pm 1.09$ & \\
\hline 39,24 & $49.64 \pm 0.59$ & \\
\hline \multicolumn{2}{|c|}{$\begin{array}{l}\text { Tabel } 2 \text {. } \\
\text { Kandungan fenolik total isolat polar fraksi heksana ekstrak etanol daun sirih }\end{array}$} & \\
\hline Replikasi & $\begin{array}{c}\text { Kadar } \\
(\% \mathrm{~b} / \mathrm{b} \text { EAG })\end{array}$ & $\begin{array}{c}\text { Rata-rata } \\
(\% \text { b/b EAG })\end{array}$ \\
\hline 1 & 24,38 & \multirow{3}{*}{$23,43 \pm 1,19$} \\
\hline 2 & 23,81 & \\
\hline 3 & 22,09 & \\
\hline
\end{tabular}

Aktivitas antioksidan isolat polar fraksi heksana ekstrak etanol daun sirih

\section{PEMBAHASAN}

Aktivitas antioksidan sampel ditentukan dengan metode peredaman radikal DPPH. Pengujian aktivitas antioksidan tersebut didasarkan pada kemampuan senyawa antioksidan untuk mendonorkan atom $\mathrm{H}$ dalam mereduksi DPPH radikal sehingga menjadi senyawa DPPH non radikal. Kemampuan peredaman radikal DPPH oleh sampel dapat dilihat dari pemudaran warna ungu larutan DPPH menjadi kuning. Parameter yang digunakan untuk menyatakan aktivitas antioksidan dengan metode peredaman radikal DPPH adalah nilai $\mathrm{IC}_{50}$ yang menyatakan 
besarnya konsentrasi senyawa uji yang dapat mereduksi radikal DPPH sebesar 50\%, diperoleh dari kurva regresi linier antara aktivitas peredaman radikal DPPH dengan konsentrasi sampel (Karim dkk., 2014). Semakin kecil nilai $\mathrm{IC}_{50}$ semakin aktif isolat (senyawa uji) tersebut sebagai aktivitas antioksidan.

Senyawa antioksidan dapat dikategorikan sangat kuat jika memiliki nilai IC $_{50}$ kurang dari $50 \mu \mathrm{g} / \mathrm{mL}$, antioksidan kuat jika memiliki nilai $\mathrm{IC}_{50}$ antara $50-100 \mu \mathrm{g} / \mathrm{mL}$, antioksidan sedang memiliki IC50 antara 100-150 $\mu \mathrm{g} / \mathrm{mL}$, antioksidan lemah memiliki $\mathrm{IC}_{50}$ lebih dari 150 $\mu \mathrm{g} / \mathrm{mL}$ (Blois dkk.,1958). Berdasarkan Tabel 1 menunjukkan bahwa isolat polar dari fraksi heksana ekstrak etanol daun sirih mempunyai nilai $\mathrm{IC}_{50}$ sebesar $37,37 \mu \mathrm{g} / \mathrm{mL}$. Hal ini menunjukkan bahwa isolat polar dari fraksi heksana ekstrak etanol daun sirih mempunyai aktivitas antioksidan sangat kuat.

Dalam penelitian ini digunakan pembanding vitamin E yang sudah diketahui aktivitas antioksidan. Hasil pengukuran menunjukkan bahwa vitamin $\mathrm{E}$ mempunyai nilai $\mathrm{IC}_{50}$ sebesar $8,41 \mu \mathrm{g} / \mathrm{mL}$ lebih kecil daripada nilai $\mathrm{IC}_{50}$ senyawa uji. Semakin kecil nilai $\mathrm{IC}_{50}$ maka semakin besar aktivitas antioksidannya. Hal ini berarti bahwa aktivitas antioksidan vitamin $\mathrm{E}$ lebih besar daripada aktivitas antiokidan isolat polar dari fraksi heksana ekstrak etanol daun sirih.

Aktivitas antioksidan yang dimiliki oleh tanaman berhubungan dengan kandungan fenolik dan flavonoid totalnya. Banyak penelitian melaporkan bahwa senyawasenyawa fenolik mempunyai aktivitas antioksidan dikarenakan senyawa fenolik mampu mereduksi senyawa-senyawa radikal (Rohman dkk., 2007).

Kandungan fenolik total dalam penelitian ini ditentukan dengan metode spektrofotometri visibel dengan menggunakan reagen FolinCiocalteu. Kandungan fenolik total dinyatakan dalam \% b/b ekivalen asam galat (\%b/b EAG). Berdasarkan Tabel 2 menunjukkan bahwa kandungan fenolik total dari isolat polar fraksi heksana ekstrak etanol daun sirih sebesar 23,43 $\%$ b/b EAG setara dengan 234,3 mg EAG/g isolat. Banyak penelitian yang melaporkan bahwa senyawa-senyawa fenolik mempunyai aktivitas antioksidan karena sifat-sifat redoksnya. Senyawa fenolik dapat mereduksi senyawa radikal dengan memberikan atom hidrogen atau sebagai peredam oksigen singlet (Rohman dkk, 2007).

\section{SIMPULAN}

1. Isolat polar fraksi heksana ekstrak etanol daun sirih mempunyai aktivitas antioksidan sangat kuat pada pengujian peredaman radikal DPPH dengan nilai $\mathrm{IC}_{50}$ sebesar $37,37 \mu \mathrm{g} / \mathrm{mL}$. Akan tetapi aktivitas antioksidan tersebut lebih kecil dibandingkan vitamin $\mathrm{E}$ ( Nilai $\mathrm{IC}_{50}$ vitamin E sebesar 8,41 $\mu \mathrm{g} / \mathrm{mL}$ )

2. Isolat polar fraksi heksana ekstrak etanol daun sirih mempunyai kandungan fenolik total sebesar 23,43 $\pm 1,19 \%$ b/b EAG. Senyawa-senyawa fenolik tersebut mempunyai aktivitas antioksidan

\section{DAFTAR PUSTAKA}

Blois M.S., 1958. Antioxidant determinations by the use of stable Free Radical.Nature, 181: $1199-1200$

Chun, O.K., Kim, D.O. dan Lee, C.Y., 2003. Superoxide radical scavenging activity of the major polyphenols in fresh plums. Journal of Agriculture and Food Chemistry, 51: 8067-8072.

Fidrianny I., Johan Y., Sukrasno, 2015. Antioxidant activities of different extracts from three organs of markut lime (citrus hystrix Dc) and correlation with total flavonoid, phenolic, carotenoid content. Asian J Pharm Clin Res, 8(4):239-243

Ghosh S., 2013. Phytochemical Analysis and Free Radical Scavenging Activity of Medicinal Plants Gnidia glauca and Dioscorea bulbifera. India : Institute of Bioinformatics and Biotechnology, University of Pune, 8:1-18.

Haryoto, 2007, Antioksidan dari Fraksi Polar Ekstrak Metanol dari Kulit Kayu Batang Shorea accuminatissima dengan Metode DPPH, Jurnal Ilmu Dasar, FMIPA UNEJ, Vol. 2, No.3: 185-195.

Karim, A.A., Azlan, A., Ismail, A., Hashim, P., Gani, S. salwa abd, Zainudin, B.H., 
dkk., 2014a. Phenolic composition, antioxidant, anti-wrinkles and tyrosinase inhibitory activities of cocoa pod extract. BMC Complementary and Alternative Medicine, 14: 381.

Moeljatno, R., 2003, Khasiat dan Manfaat Daun Sirih Obat Mujarab dari Masa ke Masa, Agromedia Pustaka, Jakarta

Molyneux, P., 2003, The Use of The Stable Free Radical Diphenylpicrylhydrazyl (DPPH) for Estimating Antioxidant Activity, Songklanakarin J. Sci. Technol., 26(2) : 2

Rohman, A., dan Riyanto, S., 2005. Daya Antioksidan Ekstrak Etanol Daun Kemuning (Muraya paniculata L (Jack)) secara In Vitro. Majalah Farmasi Indonesia, 16(3):136-140
Rohman, A., dan Riyanto S., 2007. Aktivitas antioksidan, kandungan fenolik total, dan flavonoid total daun mengkudu (Morinda citrifolia, L). Agritec, 27: 147151.

Sreenivasan, S., Ibrahim, D., and Kassim, M. J. N. M., 2007, Free radical Scaveging Activity and Total Phenolic Compounds of Gracilia changii, Internasional Journal of Natural and Engineering Science 1(3):115-117

Sumarya, I M, Adiputra, N, Sukrama, I D.M, Putra-Manuaba, I.B., 2016. Betel leaf extract (Piper betle L.) antihyperuricemia effect decreases oxidative stress by reducing the level of MDA and increase blood SOD levels of hyperuricemia wistar rats (Rattus norvegicus). Bali Medical Journal (Bali Med J), 5: 263-267 